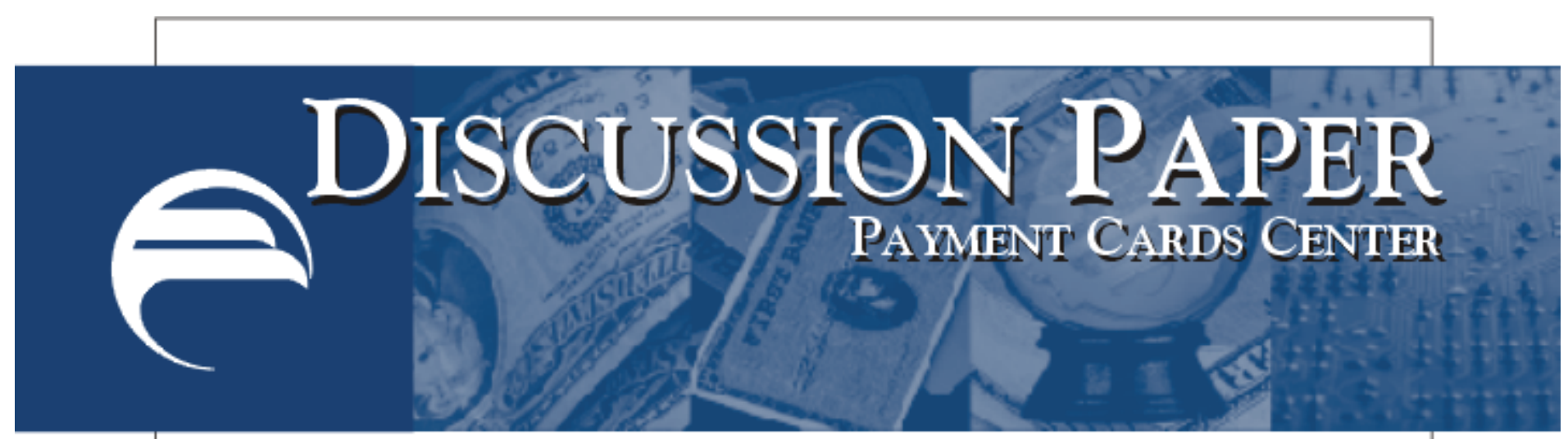

\title{
Credit Card Pricing Developments and Their Disclosure
}

\author{
Mark Furletti*
}

January 2003

Summary: Public data, proprietary issuer data, and data collected by the author from a review of over 150 lender-borrower contracts from 15 of the largest issuers in the U.S. suggest that, over the past 10 years, credit card issuers have drastically changed the way that they price their product. This paper outlines the history and dynamics of credit card pricing over the past 10 years and examines how new pricing methods are addressed by current regulatory disclosure requirements.

*Payment Cards Center, The Federal Reserve Bank of Philadelphia, Ten Independence Mall, Philadelphia, PA 19106. Email: mark.furletti@phil.frb.org. Thanks to Rick Lang, Peter Burns, Robert Hunt, Joseph Mason, Michael Heller, and Norman Lee. The views expressed here are not necessarily those of the Federal Reserve Bank of Philadelphia or of the Federal Reserve System.

\section{Federal Reserve Bank of PhiladelPhia}


Intense competition for new customers and the adoption of new technologies in the credit card industry has decreased the price of credit for most consumers as measured by one wellunderstood metric — the nominal annual percentage rate (APR). For card issuers, this has meant surrendering some of the net interest margin they enjoyed as a result of high APRs in the late 1980s and early 1990s and instituting pricing strategies that consider an individual borrower's risk and behavior profile. As nominal APRs have decreased, issuers have come to rely on new pricing techniques to maintain or increase portfolio profitability. These techniques include new APR strategies, fee structures, and methodologies to compute finance charges.

This paper outlines the history and dynamics of credit card pricing over the past 10 years and examines how pricing methods are disclosed to consumers. The analysis concludes by discussing the challenges that newer, more complex pricing strategies pose to the current disclosure framework established by the Truth in Lending Act.

\section{Background}

\section{Industry Pricing Dynamics}

Over the past 10 years, a series of innovations and market developments have significantly changed the credit card industry. Advances in credit scoring, response modeling, and solicitation technologies (e.g., e-mail, direct mail, telemarketing) have allowed experienced issuers to more efficiently market their products and enabled new issuers to enter the card market and grow quickly. ${ }^{1}$ At the same time, it has become easier for consumers to find better credit card alternatives and move their card balances from one issuer to another.

From 1991 to 2001, the number of mailed credit card solicitations increased fivefold to 5.01 billion (Figure 1). According to BAI Global, these solicitations in 2001 reached 79 percent of U.S. households, which, on average, received five offers each month. ${ }^{2}$ Issuers' aggressive mail

\footnotetext{
${ }^{1}$ In the eight months since launching its Visa program at the end of 2001, Target Corporation issued 6 million credit cards and captured over $\$ 2$ billion in outstandings. Similarly, other new entrants like Sears and Juniper Bank have been able to grow very rapidly and compete against much larger issuers.

${ }^{2}$ Compared with 73 percent of U.S. households receiving four offers in 2000.
} 
marketing efforts have been augmented by telephone, event, and Internet campaigns such that most consumers do not have to work very hard to find a new card. Product innovations, such as transferring balances and eliminating annual fees, have also made it easier for customers to switch cards. Customer loyalty, once ensured by an annual fee and a revolving balance built through years or months of purchases, can now be easily captured by competitors with a no-fee, low-rate offer to transfer balances.

As a result of these developments, issuers have struggled to maintain customer loyalty through rewards programs, affinity/co-brand relationships, and enhanced customer service. Despite these efforts, a card's nominal APR remains one of its most distinguishing characteristics. The envelopes, letters, and applications that issuers use to solicit new business focus potential customers' attention on either very low introductory APRs (e.g., 0.0 percent, 1.9 percent) or low permanent APRs (e.g., 7.9 percent, 9.9 percent, 12.9 percent).

Low rates, however, are relatively new phenomena in the card industry. Researchers studying the card industry in the 1980s and early 1990s found that credit cards had substantially higher rates and returns than most other bank credit products (Ausubel, 1991). Further research showed that credit card rates remained high when other interest rates fell, leading Calem and Mester to conclude that card rates in that environment were "sticky" (Calem and Mester, 1995). The data in Figure 2 illustrate this stickiness through $1992 .^{3}$

From 1992 to 2001, however, the average interest rate that issuers charged revolving customers fell 320 basis points, from 17.4 percent to 14.2 percent. Issuer markup, a metric that normalizes for funding costs by subtracting the six-month Treasury bill rate from the average APR, decreased 330 basis points during the same period (Figure 3). Margins also narrowed compared with those of other consumer loan products. The difference between the average interest rate charged on a 24-month personal installment loan and a revolving credit card loan fell 
from 3.8 percent in 1992 to 1.6 percent in 2001 (Figure 4). Taken together, it is clear that for low-risk consumers who have revolving balances, credit card costs, as measured by APR, have significantly declined over the past 10 years.

At the same time, more consumers gained access to credit cards, including those with lower incomes. Between 1989 and 1998, the largest increases in bankcard ownership were observed among consumers with the lowest levels of income (Durkin, 2000). ${ }^{4}$ With generally lower liquidity buffers and weaker credit histories, lower income consumers are typically assessed higher annual percentage rates. An overall decrease in the average APR, coupled with an increase in the number of lower income credit users, suggests that the average rate decrease for many cardholders was even more pronounced than the average APR indicates.

Consumer awareness of annual percentage rate as a key cost measure, combined with the ability to easily find new card offers and switch issuers, inevitably affected price competition and rate stickiness. According to surveys conducted in 2000 by the Survey Research Center of the University of Michigan, 91 percent of consumers who have a credit card are aware of the APR they are charged on their outstanding balances, based on a "broad" definition of awareness (Durkin, 2000). ${ }^{5}$ Federal Reserve Board economist Thomas Durkin concludes that "it is clear that awareness of rates charged on outstanding balances... has risen sharply since implementation of the Truth in Lending Act" in 1968.

\footnotetext{
${ }^{3}$ This paper is primarily focused on pricing changes that occurred in the mid- to late-1990s. For detailed information about credit card pricing in the 1970s and 1980s, the reader may want to refer to Lewis Mandell's The Credit Card Industry: A History (G. K. Hall \& Co., 1990).

${ }^{4}$ The following are the changes in the percentage of respondents to the survey cited by Durkin by income quintile who indicated that they owned a bank-type credit card: lowest +65 percent; second lowest +61 percent; middle +16 percent; second highest +13 percent; highest +7 percent.

${ }_{5}^{5}$ Awareness was measured using a narrow and a broad definition. Under the broad definition, only those reporting that they did not know the rate were considered unaware. Under the narrow definition, those reporting a rate less than 7.9 percent were also considered unaware. Using the narrow definition, awareness in 2000 was measured at 85 percent. Previous measures of awareness from the Survey of Consumer Finance did not distinguish between narrow and broad. These measures showed 27 percent in 1969, 63 percent in 1970, and 71 percent in 1977.
} 


\section{The Truth in Lending Act and Price Disclosure}

The Truth in Lending Act (TILA) was enacted as Title I of the Consumer Credit Protection Act in 1968. The act stated that "economic stabilization would be enhanced and that competition would be strengthened by the informed use of credit resulting from an awareness of credit costs on the part of consumers." TILA charged the Federal Reserve with creating and enforcing the specific rules needed to implement the legislation. These rules are embodied in the Board of Governors' Regulation Z (Truth in Lending).

Truth in Lending, as it applies to credit card accounts, is primarily disclosure focused. The act is silent about the number, amount, variety, or frequency of fees and credit-related charges that issuers can impose. It does not suggest ceilings, price controls, or limits for any charges. Instead, it requires that issuers inform potential customers about specific pricing terms at specific times. Regulation Z specifies that select terms be disclosed at specific points, including the following: upon solicitation or application; before first use of the card; and upon receiving a statement. ${ }^{6}$ The level of detail for disclosure at each point varies (Table 1).

When first promulgated, Truth in Lending rules required that issuers of credit cards disclose information about the computation of APRs and finance charges to customers "before the first transaction [was] made" on the account. To meet this requirement, issuers mailed consumers a "single written statement" that explained the costs of the card after his or her account was opened.

Since 1968 both Congress and the Board of Governors ("the Board") have mandated changes to Truth in Lending disclosure requirements. One of the most well-known features of Truth in Lending, a pricing disclosure box, resulted from the amendment of TILA by the Fair Credit and Charge Card Disclosure Act of 1988. Informally referred to as the "Schumer box" after the congressman from New York who was instrumental in the legislation's passage, the box 
displays APR and fee information on card applications and solicitations in a table designed to be easy for consumers to read and use for comparison purposes. By requiring that issuers display this box on applications and solicitations, the act enabled consumers to compare offers and rates before opening an account. An example of the "Schumer box" is shown in Table 2.

Similarly, in response to the potentially confusing number of different APRs that can now be associated with a single credit card account (e.g., balance transfer APRs, cash advance APRs, purchase APRs), the Board further modified Regulation $\mathrm{Z}$ in 2000. As a result of this modification, issuers are required to disclose the APR for purchases in at least 18-point type on applications and solicitations. The modification also requires them to disclose balance-transfer fees that apply to an account.

The Board, through modifications to Regulation Z, and Congress, through legislation, have updated Truth in Lending to take into account product evolution. Recent changes in how issuers price credit cards, however, have resulted in new levels of pricing complexity and created a structure of credit costs that can impact some customers very differently than others. That is, the cost that a consumer faces greatly depends on the way he or she uses the credit card.

This paper will explore the evolution of credit card pricing and examine the disclosure requirements of Truth in Lending (Regulation Z) that relate to these pricing changes. Analysis will rely on public data, proprietary issuer data, and data collected by the author from a review of over 150 lender-borrower contracts from 15 of the largest issuers in the U.S. over a five-year period. ${ }^{7}$ Pricing and fee changes are organized into three categories — nominal APR changes, fee structure changes, and computational technique changes - and presented in order of most to

\footnotetext{
${ }^{6}$ Regulation $\mathrm{Z}$ also requires that specific information be disclosed in advertisements for credit (e.g., ads on television or in magazines) and when certain credit terms are changed. This paper does not examine these regulatory disclosure requirements.

${ }^{7}$ Lender-borrower contracts are the documents issuers send their customers that often include fee disclosures, account usage terms and conditions, borrower and lender responsibilities, etc. Issuers typically refer to them as Cardmember Agreements or Required Disclosures, and modify them with Change in Term Notices. These documents are usually made available to cardholders before the first transaction is made on the account.
} 
least consistent with the current format of regulatory disclosure requirements. Examples of each type of change are provided, along with an analysis of each change's impact on issuers' revenues.

\section{Nominal APR Changes}

Until the early 1990s, credit card pricing, as it related to nominal APRs, might best be characterized in two ways: high and simple. Card issuers generally had one or two card products

(e.g., a classic card and/or a gold card) that each had a single annual percentage rate of around 18 percent. If an applicant for credit could pass the risk threshold set by the issuer, he or she would receive a card. If the applicant's credit behavior was determined to be too risky, his or her application was denied. This resulted in a portfolio of customers who were priced as if they had very similar probabilities of default.

Evidence of these risk-indifferent APR strategies can be observed in public "rate decrease announcements" that issuers released to the media in the early 1990 s. $^{8}$ At the time, issuers generally had one rate that they extended to all customers. When they lowered this rate, they did so for almost all of their accounts. A 1993 issue of CardTrack, a publication of CardWeb.com, reported that Citibank was offering a 15.4 percent rate to all new applicants. This was the same rate it was offering to virtually all of its current customers. CardTrack also reported that 90 percent of Citibank cardholders had been paying an APR of 19.7 percent a few years earlier. Other large issuers, such as Chase, Chemical, AT\&T, and Bank One, made rate-cut announcements that were similarly applied to all current and new customers (Stango, 2002). Competitive pressures and increasing price awareness among consumers, however, eventually made these undifferentiated pricing strategies obsolete.

\section{Risk-Based Solicitation APRS}

Issuers have generally used risk-based pricing techniques in two ways. The first is in setting the interest rate initially offered to a consumer. Using credit bureau attributes, issuers 
assess the default risk of a consumer and essentially charge him or her a premium for that risk. This premium is typically reflected in the APR stated in the card application or solicitation.

Prior to the early 1990 s, by charging every customer the same rate, issuers made much higher profits from customers with very low default risk. ${ }^{9}$ These excess profits could be used to cover defaults generated by customers whose risk, over time, had increased. As issuers began competing on APR, however, they were forced to eliminate this cross-subsidization and assess APRs based on an analysis of individual borrower risk.

Ultimately, a card's nominal APR became a competitive focal point and drove widespread adoption of risk-based pricing. Issuers who failed to adjust pricing appropriately by risk segments would expose themselves to serious adverse selection problems. Issuers today may have hundreds of different APR price points. With few exceptions, these points are highly correlated to some risk measure. ${ }^{10}$ Figure 5 illustrates how lower-risk borrowers have benefited from risk-based pricing. This figure uses account pricing and yield data gathered from a group of top prime issuers by Argus Information \& Advisory Services, a financial services consulting firm based in White Plains, New York. The graph shows the difference between the effective finance charge yield for the highest risk revolving customers (FICO scores less than 600) and customers in other risk cohorts (data from 1992 are estimated from rate announcements). The 1998, 2000, and 2002 Argus data illustrate that the discount that lower risk customers receive on their APR has increased significantly since the early days of risk-indifferent pricing. The lowest risk customers, who once paid the same price as high-risk customers, now enjoy rate discounts that

\footnotetext{
${ }^{8}$ Stango (2002) observes that comments about high card rates from President George H. Bush in 1991 and the Senate's passage of a bill in that same year capping APRs influenced many large issuers to lower rates. (The Senate's bill was never signed into law.)

${ }^{9}$ The risk-based pricing techniques referred to in this section impact customers only to the extent to which they carry a balance on their credit card. For customers who always pay their balance in full, such pricing techniques are effectively inconsequential.

${ }^{10}$ One notable exception to the risk-based pricing strategy is the co-branded airline portfolio. Co-branded air cards that reward users with frequent-flyer miles typically attract low-risk business travelers despite having a high rate (e.g., 18.9 percent) and an annual fee.
} 
can reach more than 800 basis points. ${ }^{11}$ At the other end of the risk spectrum, these strategies have enabled issuers to grant more people (e.g., immigrants, lower income consumers, those without any credit experience) access to credit, albeit at higher prices. Former Federal Reserve Governor Lawrence Lindsey has referred to this phenomenon as "the democratization of credit" (Black and Morgan, 1998). Examining data from the Survey of Consumer Finance, Stavins also noted the same risk-based pricing trend. She observes that "consumers with higher ratios of unpaid credit card debt to income, and thus [who were] worse credit risks for the issuers, were charged higher interest rates" (Stavins, 2000).

\section{Risk-Based Penalty APRs}

Risk-based pricing strategies can also be used to modify a customer's APR after he or she has started using the account. Issuers have recently implemented "penalty APR" strategies that allow them to adjust upward the nominal APR of customers whose risk, perhaps because of recent late payments or increasing levels of debt, is no longer in line with their original APR. ${ }^{12}$ In the author's study of lender-borrower contracts, the introduction of penalty pricing strategies was observed in the late 1990s. ${ }^{13}$ An example of language that explained these policies in 1997 read as follows: "Your APRs may increase if you fail to make a payment to us when due, you exceed your credit line, or you make a payment to us that is not honored by your bank." The same study revealed that issuers had taken these policies a step further in recent years. Agreements were changed to allow issuers to incorporate into the penalty pricing decision information they

\footnotetext{
${ }^{11}$ One could argue that the customers at any given FICO score might be riskier today than in 1998 (i.e., a 650 FICO score in 2002 carries a higher risk of default than a 650 did in 1998) because of changes in issuers' underwriting standards or a less favorable economic environment. There are three reasons to doubt the material impact of such factors. First, in an attempt to control for the impact of economic cycles, the data are presented relative to the yield of highest risk customers (FICO scores $<600$ ). Second, credit modeling experts believe that Fair Isaac frequently recalibrates its FICO model in order to ensure that its score-odds ratio is relatively stable. This mitigates the effects that different economic environments might have on the score. Finally, the underwriting standards of the prime/super-prime issuers in the Argus study are thought to have been stable throughout the period with little or no sub-prime origination.

${ }^{12}$ Penalty pricing tactics employed by Direct Merchants (Metris) led CardTrack to observe that "credit card interest rates have passed the 30\% barrier!" As reported in May 2000, a 31.99 percent APR was imposed on Metris customers who were late three times during the year or who fell 60 days delinquent.
} 
obtained from credit bureaus about other loan behavior. Newer policies read as follows: "We may increase the annual percentage rate on all balances to a default rate of up to 24.99 percent... if you fail to make a payment to us or any other creditor when due, you exceed your credit line, or you make a payment to us that is not honored by your bank" [emphasis added]. ${ }^{14}$

\section{Nominal APR Changes and Regulatory Disclosure Requirements}

The risk-based pricing strategies described above are exclusively focused on the nominal APR component of credit card pricing. Disclosures required by Regulation Z inform customers about such APRs upon solicitation in two sections of the "Schumer box" (i.e., Annual Percentage Rate (APR) for Purchases; and Other APRs) and on periodic statements (i.e., Annual Percentage Rate). In addition, Regulation $\mathrm{Z}$ requires that the nonintroductory purchase APR be displayed in 18-point type in the "Schumer box" on new card offers.

Overall, Truth in Lending disclosure requirements ensure prominent display of each APR associated with an account. The nominal APR-focus of Truth in Lending statements and of issuers' marketing materials has no doubt contributed to consumer awareness of APRs as key determinants of credit cost.

\section{Fee Structure Changes}

Another way that credit card pricing has developed is in the "unbundling" of costs in the form of fees. As previously mentioned, card pricing in the 1980s and early 1990s was relatively simple. Issuers typically charged a relatively high interest rate and an annual fee of around \$25 that covered most of the expenses associated with card usage. Few issuers charged over-limit fees or late fees, and when they did, these fees were relatively small. ${ }^{15}$ The increased competition for new accounts that developed in the mid-1990s, however, changed all of this. Rates came down, as

\footnotetext{
${ }^{13}$ The author would like to thank MarketIQ, a direct marketing competitive intelligence firm in Fair Haven, New Jersey, for contributing to the author's study.

${ }^{14}$ Some issuers' policies explained that a consumer could get his or her pre-penalty rate back after making 12 consecutive on-time payments.

${ }^{15}$ Typical late fees ranged from $\$ 5$ to $\$ 10$. The average late fee charged in 1990 , according to CardWeb, was $\$ 9$.
} 
described in the previous section, and issuers eliminated the once universal annual fee. Today, these fees are almost nonexistent in prime portfolios not associated with a rewards program. The data that Argus Information \& Advisory Services collected from top issuers show that just 14 percent of customers who are not enrolled in a rewards program (e.g., a frequent-flyer-miles program) paid an annual fee in 1998 and just 2 percent did in $2002 .{ }^{16}$

With average interest rates on the decline and annual fees becoming unpopular among their customers, issuers developed more targeted fee structures to replace lost revenues. In lieu of charging all of their customers an annual fee that subsidized the costs associated with the behaviors of a few, they began to assess fees directly on those customers whose card usage behaviors drove costs higher. As issuers started unbundling costs and creating behavior-based fees, fees rebounded and have again become an important component of issuer revenues (Figure 6). Ultimately, two distinct families of fees have emerged: risk-related fees and convenience/service fees.

\section{Risk-Related Fees}

In addition to using different APRs to better price for risk, issuers have significantly increased the use of risk-related fees. These include late fees, over-limit fees, and bounced-check fees. The industry's modeling and analysis efforts have shown that customers who are late or over their credit limit or who write bad checks are more likely to default. Risk-related fees help compensate issuers for this increased risk. ${ }^{17}$ For lower risk customers, risk-related fees can deter sloppy payment behavior and poor credit-line management.

The examination of lender-borrower contracts from 1997 through 2002 revealed that issuers significantly increased traditional risk-based fee levels and created new fees. For example, in 1997, the risk-based fee that most issuers charged customers who had exceeded their credit line

\footnotetext{
${ }^{16}$ The data from Argus also show that the average annual fee charged on a nonrewards card has fallen from $\$ 3.31$ in 1998 to $\$ 0.50$ in 2002 .

${ }^{17}$ Issuers may also be aware that customers who are consistently paying these fees are likely to have fewer and less attractive credit alternatives.
} 
was less than $\$ 20$. By 2002, most top issuers had adopted an over-limit fee structure that was tiered by balance size and nearly doubled the fee for over-limit customers. These issuers now assess a $\$ 35$ fee to those customers who exceed their credit line and have a balance of over $\$ 1000$. Similar increases were observed for late fees and returned-check (NSF) fees. ${ }^{18}$ Evidence of the impact of these increases on the average late fee can be seen in Figure 7.

Issuers were also observed introducing new risk-based fees during this period. For example, in the late 1990s, issuers began assessing a returned-check fee for credit card convenience checks. Such checks allow customers to access their credit card's line of credit using a paper check. If a customer writes a convenience check for an amount that exceeds his or her available credit line and the issuer chooses not to honor the check, most issuers now assess that customer a fee that ranges from $\$ 29$ to $\$ 35$.

The impact of higher risk-based fees on issuers' revenues has been substantial. In May 2002, Cardweb.com estimated that half of all consumers in the U.S. who had a credit card had been late at least once in the previous 12 months. Issuers' annual late fee revenues more than quadrupled from 1996 to 2001 ( $\$ 1.7$ to $\$ 7.3$ billion) while average late fees only doubled ( $\$ 13$ to \$27). This indicates that, in addition to an increase in the amount of the average late fee, there has been a substantial increase in late fee incidence. Cardweb.com also noted that late-fee revenue currently represents the third largest revenue stream for issuers after interest and interchange revenue. ${ }^{19}$ Argus Information \& Advisory Services data compiled from top prime issuers during the first quarter of 2002 showed that 5 percent of issuers' active cardholders were assessed an over-credit-limit fee during the three-month period. Information on the size and growth of other risk-based fee types is not available. The examples above, however, strongly suggest that risk-

\footnotetext{
${ }^{18}$ NSF is a return check reason code that stands for "not sufficient funds."

${ }^{19}$ Interchange revenue is derived from a fee set by the card associations that issuers assess merchants each time a credit card purchase is made. Depending on the card association, the fee can range from 1.5 to 4.0 percent of the value of the transaction.
} 
based fees have become an important source of revenue for card issuers and have replaced a significant portion of the revenues lost from the elimination of annual fees and lowered APRs. Convenience and Service Fees

Issuers have also unbundled servicing costs, introducing fees for services and conveniences that were once paid for by all customers out of annual fee and interest revenues. Some of these new fees, like those levied on the credit card purchase of casino chips or on cash advances, compensate issuers for the fraud risk thought to be inherent in cash or cash-equivalent transactions. Other fees, like those imposed for stop payment requests, statement copies, or replacement cards, more directly compensate issuers for out-of-pocket expenses (e.g., customer service representative time, telecommunications expense). In addition to defraying operational costs, these new fees are generally priced to provide attractive profit margins.

Table 3 lists 11 changes to convenience and service fees observed in the author's lenderborrower contract research. Three of these are described in more detail below.

Starting in the late 1990s, a number of issuers began assessing a foreign currency conversion fee of 2 percent on purchases that cardholders make outside the U.S. This fee was added on top of a 1 percent fee already assessed by MasterCard and Visa. The 1 percent fee charged by the associations covers the transaction costs associated with the actual exchange. Some industry sources suggest that the 2 percent fee levied by issuers is related to the longdistance telecommunications charges associated with customer service calls that originate in foreign countries from traveling customers.

More recently, several issuers have added a phone payment convenience fee. This fee, which ranges between $\$ 10$ and $\$ 25$, is assessed when customers choose to pay over the phone instead of through the mail. ${ }^{20}$ While this fee may seem like an expensive alternative when

\footnotetext{
${ }^{20}$ When an issuer accepts a payment over the phone, it receives authorization from its customer to debit the customer's checking account for the payment amount.
} 
compared to the cost of postage, customers who typically rely on phone payments are often close to missing their payment due date and being assessed a $\$ 35$ late fee.

Finally, most issuers have adopted balance transfer fees. These fees, typically around 3 percent of the amount transferred with various minimums and maximums, are often assessed on balances transferred from a competitor's card. These balances often qualify for a discounted promotional APR. The balance transfer fee helps offset costs associated with customer service representatives who initiate the balance transfers and may help reduce "rate surfing" (i.e., the act of continually moving balances among cards to take advantage of short-term promotional rates). ${ }^{21}$

Information on the revenue impact of convenience and service fees is limited. Argus Information and Advisory Services data indicate that the top prime issuers are earning about $\$ 8$ per active account per year in cash advance fees and $\$ 6$ per active account per year in other fees (excluding risk-related fees). The actual impact that fees have on revenue per account can be observed only among the few issuers who separately list nonsecuritization fee income in their annual reports. One such annual report revealed a doubling of fee revenue per account from $\$ 4$ in 1998 to $\$ 8$ in 2001.

Fee Changes and Regulatory Disclosure Requirements

Regulation $\mathrm{Z}$ requires that issuers, upon application or solicitation, inform customers about the annual fee, minimum finance charge, cash advance fee, balance transfer fee, late fee, and over-limit fee associated with an account. Before the first transaction is made on the account, issuers must disclose "other charges," that is "any charge other than a finance charge that may be imposed as part of the plan, or an explanation of how the charge is determined." The official staff commentary on Regulation Z, which represents the Board staff's interpretations of the regulation, further provides that only "significant charges" must be disclosed as "other charges." The

\footnotetext{
${ }^{21}$ If these fees become universally adopted, they will make it more expensive for consumers to switch cards.
} 
commentary offers late fees, annual fees, over-limit fees, and account closure fees as examples of "significant charges."

Regulation $\mathrm{Z}$ does not explicitly address disclosure of the foreign currency conversion fee. Unlike most fees that can be observed upon a detailed review of a card statement, foreign currency conversion fees are often rolled into the transaction amount or the conversion factor. ${ }^{22}$ Other fees that are not specifically mentioned in the regulation include phone payment fees, wire transfer fees, and stop payment fees on credit card convenience checks. ${ }^{23}$ Issuers generally disclose these fees to consumers by including a menu or a description of these other fees in "welcome kit" mailings to new customers or in "Cardmember Agreements." The organization, detail, and prominence of these menus or descriptions vary by issuer.

\section{Computational Technique Changes}

In addition to adopting risk-based pricing and expanding fees, issuers are employing new computational practices that increase effective yields without affecting the disclosed nominal APRs. The author's lender-borrower contract research uncovered six examples among the major issuers. Three of the more common practices are detailed below; explanations of the remaining three can be found in Table 4 .

\section{Payment Allocation}

Many issuers have added sections to their contracts to explain how they allocate payments to revolving balances. As mentioned previously, the number of APRs that can be applied to the balances on an account has increased dramatically over the past 10 years (e.g., purchase APR, promotional APR, cash APR, balance transfer APR). Issuers have created various average daily balance categories to which these different rates are applied. One issuer's disclosure statement explained the way in which payments would be applied to different balance categories

\footnotetext{
${ }^{22}$ In a New York Times article, "Credit Card Swipe: Concealed Charges," reporter Susan Stellin noted that just three major issuers separate out their foreign currency exchange charges on customers' statements.
} 
as follows: "We will allocate your payment and any credits to pay off balances at low periodic rates before paying off balances at higher periodic rates." This computational methodology effectively "protects" revolving balances at higher rates. For example, issuers can offer a customer with a $\$ 2500$ revolving balance at 18.9 percent an opportunity to transfer another $\$ 2500$ balance onto the card at an APR of 2.9 percent. Since the customer's payments are allocated to the 2.9 percent balance first, the issuer effectively "protects" or locks in the $\$ 2500$ balance at 18.9 percent until the lower rate balance is repaid.

\section{Compounded Interest}

By 1997, most issuers had switched from monthly to daily compounding of interest by changing the computational method for calculating average daily balances. Before the adoption of daily compounding, disclosures typically explained that "on each day of the billing period we subtract payments, add new purchases and fees, and make adjustments" to calculate the average daily balance. By the end of the 1990s, however, the language had changed as follows: "To get the daily balance we take the beginning balance for every day, add any new transactions, fees, and any finance charge on the previous day's balance, subtract any credits or payments, and make other adjustments [emphasis added]." By adding finance charges to the balance each day, issuers increased finance charge revenue without increasing stated annual percentage rates. ${ }^{24}$ This has the effect of increasing the effective finance charge yield of a portfolio by as much as 10 to 20 basis points. For instance, the annual effective portfolio yield on a loan with an APR of 18.99 percent compounded 12 times a year is 20.73 percent. If the same loan is compounded 365 times per year, its effective yield increases 18 basis points to 20.91 percent.

\footnotetext{
${ }^{23}$ On November 26, 2002, the Board proposed credit card-specific revisions to Regulation Z's official staff commentary. One of these revisions would add phone payment fees to the list of "other charges" that must be disclosed before the first transaction occurs on an account.

${ }^{24}$ The annual percentage rate (APR) disclosed on a customer's statement is calculated by dividing finance charges for the period by the average daily balance for the period. While increasing the frequency of compounding increases the finance charge (i.e., the numerator), adding finance charges to the average daily balance (i.e., the denominator) each day offsets the effect of compounding on the disclosed APR.
} 


\section{Double-Cycle Interest}

Another pricing innovation involves a change in the treatment of the grace period during which interest does not accrue. One of the unique advantages of credit card borrowing has been the interest-free period consumers who pay their bill in full receive from the time they make a purchase until the date their payment is due. This period can vary from 40 to 60 days. The lenderborrower contract study revealed that a number of issuers have effectively eliminated the grace period for consumers who, after making a full payment or not having had a balance in the previous month, do not make a full payment in the next month.

For example, consider a customer without a previous balance who has a 10 percent APR on purchases and who makes a purchase of $\$ 1000$ on May 1 (the first day of the customer's May cycle). The customer then receives a bill for $\$ 1000$ on June 1 . Instead of paying the entire balance, the customer sends the issuer a minimum payment of $\$ 20$, which arrives on June 30 . When the customer's account cycles on the night of June 30, the issuer will assess finance charges for the month of June and reach back and add finance charges for the entire month of May. In this example, instead of billing approximately $\$ 8$ in finance charges (based on the APR of 10 percent), the issuer will bill approximately $\$ 16$. It should be noted that double-cycle interest is assessed only in the month in which a customer moves from a nonrevolving to a revolving state. The interest computation returns to a single-cycle method for the remaining months in the revolving period.

Data on the revenue impact of the changes described above and in Table 4 are limited.

Given that approximately three-fifths of all cardholders pay interest on their balance and that half of those who pay interest make only the minimum payment (CardWeb, March 7, 2002), it seems likely that these changes have had at least a material effect on issuers' revenues and have contributed to the shift in industry revenue profiles. 


\section{Computational Technique Changes and Disclosure Requirements}

Double-cycle billing is explicitly addressed by Regulation Z in a section of the "Schumer box" entitled "Method of Computing the Balance for Purchases." Here issuers are required to indicate the balance-computation technique they use with one of the following descriptors: average daily balance (including new purchases), average daily balance (excluding new purchases), two-cycle average daily balance (including new purchases), two-cycle average daily balance (excluding new purchases), adjusted balance, or previous balance. Additional explanations or definitions are not required by the regulation upon solicitation or application. Issuers are not required to provide detailed explanations of balance-computation techniques until after the account is opened. This means that consumers wanting to find out what the term "twocycle average daily balance" signifies before filling out an application for a card would have to conduct their own research. As a practical matter, this may be easier for consumers with access to the Internet than for others. ${ }^{25}$

Detailed descriptions of the practices referred to above and in Table 4 are usually not featured in application or solicitation materials. ${ }^{26}$ Issuers disclose the details of these computational techniques in various ways in their lender-borrower contracts and factor their effects into TILA-required periodic statement disclosures. For example, consumers who revolve a balance might become aware of the impact of daily compounded interest if, upon receiving their statement, they carefully review the issuer's calculation of the total finance charges disclosed on their statement. Similarly, customers who pay finance charges on their late fees, on their balance between the statement date and payment date, or from their transaction date to their posting date might notice, upon an exceptionally careful review, increased finance charge amounts on their statement.

${ }^{25}$ A search on "two-cycle average daily balance" on Google.com returns 10 nongovernmental, consumeroriented web sites (such as practicalmoneyskills.com, credit-cards.com, bankrate.com) that explain how two-cycle interest can influence the cost of credit. 


\section{Conclusion}

Substantial changes in the dynamics of credit card pricing have occurred over the past decade. The relatively straightforward pricing model of a single APR, an annual fee, and modest penalty fees has been replaced by a model with a complex set of APRs, new and increased fee structures, and sophisticated finance charge computation techniques. This "unbundled" pricing structure has created a card product for which consumers pay substantially different prices based on individual behavior. During this time, however, the overall disclosure framework mandated by the Truth in Lending Act has changed very little. ${ }^{27}$

The adoption of new pricing structures has increased credit costs for some consumers and decreased it for others. Low-risk borrowers, who behave in such a way as to avoid new and increased fees, generally experience lower credit costs than they might have several years ago. Higher risk borrowers, who may not have previously qualified for unsecured credit, can now obtain credit cards by paying a risk premium. Other borrowers, because of their consumption of fee-based services or perceived level of risk, now face higher credit costs. To a large extent the new pricing structure results in more credit card users "paying their own way."

A pricing structure that better allocates issuer's risk and servicing expenses has likely come at a cost in the form of a complex and customized product whose pricing is difficult to summarize. In today's environment of highly individualized pricing, it is difficult to imagine a generic disclosure requirement that could meet the burden of clearly explaining the total costs of credit that any given consumer would face. In 1996, in a report to Congress on TILA, the Board of Governors foresaw this possibility when it reported the following: "The ability to ensure accurate disclosure of the "true" costs gets more difficult as creditors increase the number of

\footnotetext{
${ }^{26}$ The balance computation technique is disclosed with a brief descriptor in the "Schumer box," but this descriptor doesn't give consumers the details necessary to understand how the interest is actually computed. ${ }^{27}$ As previously mentioned, the last major modification occurred with the passage of the Fair Credit and Charge Card Disclosure Act (FCCDA) 14 years ago. The FCCDA amended TILA and introduced the conspicuously placed "Schumer box." Since that time, the Board of Governors has modified TILA's underlying regulation and regulation staff commentary to respond to some of these pricing changes (e.g.,
} 
credit products, pricing alternatives, and optional services. The permutations of possible costs to be disclosed — and the potential for error - also increase." ${ }^{28}$

While some of the pricing innovations described in this paper might easily fit into the existing regulatory disclosure format, it is clear that others pose significant disclosure challenges. Is there a simple way to communicate two-cycle billing such that consumers understand that their credit costs will be higher if they occasionally revolve balances? Can payment allocation methods be explained in a way such that customers with low-rate promotional balances understand the cost implications of making higher-rate purchases? Is there a simple way to explain that when consumers miss a payment with one issuer, it can affect the price they pay for credit to another?

Recent survey results indicate that consumers have mixed feelings about Truth in Lending statements. In his paper entitled "Consumers and Credit Disclosures: Credit Cards and Credit Insurance," economist Thomas Durkin (2002) points out that, in consumer surveys conducted for the Board of Governors in 1994, 1997, and 2001, over three-quarters of respondents agreed that Truth in Lending statements are complicated. ${ }^{29}$ Forty percent of those surveyed did not find the statements helpful as they relate to bank-type credit cards, and 77 percent said that the statements did not affect their decision to use credit cards in any way. Although consumers may find these disclosures complex and not always helpful, Durkin concludes that consumers "appear to like knowing that the behavior of creditors is being monitored."

Based on this survey data, it is not clear that requiring more details in regulatory disclosures would be useful for consumers. An alternative is to promote understanding of credit

requiring larger point type, penalty rate disclosures, and cash advance and balance transfer APR disclosures).

${ }^{28}$ From the Board of Governors' Report to Congress, Finance Charges for Consumer Credit under the Truth in Lending Act, April 1996, p. 8.

${ }^{29}$ This includes Truth in Lending statements required for credit cards, home equity loans, and installment loans. 
costs through education. Educated consumers can change the terms on which issuers compete and force transparency in price structures. In either case, understanding new developments in credit card pricing is important for ensuring that information is available for consumers to make an informed decision about credit. 


\section{Sources}

Argus Information \& Advisory Services, White Plains, NY, Issuer Pricing Data, July 2002.

Ausubel, Lawrence M. "The Failure of Competition in the Credit Card Market," American Economic Review, March 1991, pp. 50-81.

BAI Global, "All Time Record High Credit Card Mail Volume Set in 2001," press release, $<$ http://www.baiglobal.com>, April 2002.

Black, Sandra E., and Donald P. Morgan. "Risk and the Democritization of Credit Cards," Federal Reserve Bank of New York, Research Paper 9815, 1998.

Board of Governors of the Federal Reserve System. The Profitability of Credit Card Operations of Depository Institutions, Annual Report to Congress, June 2002.

Board of Governors of the Federal Reserve System. Federal Reserve Bulletin. February 1969, pp. 126-149.

Board of Governors of the Federal Reserve System, Federal Reserve Statistical Release G.19Consumer Credit, 1972-2002.

Board of Governors of the Federal Reserve System. Finance Charges for Consumer Credit Under the Truth in Lending Act, Report to Congress, April 1996.

Board of Governors of the Federal Reserve System. Regulation Z.

Board of Governors of the Federal Reserve System. Official Staff Commentary on Regulation Z.

Business Week Online. "Target Takes a Gamble That Markets Don't Like," $<$ http://www.businessweek.com/magazine/>, April 1, 2002.

Calem, Paul S., and Loretta J. Mester. "Consumer Behavior and the Stickiness of Credit-Card Interest Rates," American Economic Review, December 1995, pp. 1327-36.

Cardweb.com, CardTrack. "31.99\% APR," <http://www.cardweb.com/cardtrack/> May 2000.

Cardweb.com, CardTrack. "Big Guy Fight," <http://www.cardweb.com/cardtrack/> July 2000.

Cardweb.com, CardTrack. "Card Leaders," < http://www.cardweb.com/cardtrack/> May 24, 2002.

Cardweb.com, CardTrack. "Fee Frenzy," <http://www.cardweb.com/cardtrack/> March 21, 2002.

Cardweb.com, CardTrack. "Late Fee Bug," <http://www.cardweb.com/cardtrack/> May 17, 2002.

Cardweb.com, CardTrack. "Minimum Payments," <http://www.cardweb.com/cardtrack/> March 7, 2002. 
Cardweb.com, CardTrack. "National Credit Education Week," <http://www.cardweb.com/ cardtrack/> April 1993.

Cardweb.com, CardTrack. "Profit Squeeze," <http://www.cardweb.com/cardtrack/> October 1999.

Durkin, Thomas A. "Credit Cards: Use and Consumer Attitudes, 1970-2000," Federal Reserve Bulletin, September 2000, pp. 623-34.

Durkin, Thomas A. "Consumers and Credit Disclosures: Credit Cards and Credit Insurance," Federal Reserve Bulletin, April 2002, pp. 201-13.

Federal Deposit Insurance Corporation, commercial bank profitability press releases, 1994-2001.

Juniper Bank. "Juniper Bank Passes \$100 Million Milestone," press release, December 18, 2000.

MarketIQ, Fair Haven, NJ, Lender-Borrower Contracts, July 2002.

Stango, Victor. "Strategic Responses to Regulatory Threat in the Credit Card Market," Federal Reserve Bank of Chicago Working Paper 2002-02, February 2002.

Stavins, Joanna. "Credit Card Borrowing, Delinquency, and Personal Bankruptcy," New England Economic Review, July/August 2000, pp.15-30.

Stellin, Susan. "Credit Card Swipe: Concealed Charges," New York Times, July 12, 2002.

U.S. House of Representatives, House Report No. 90-1040 on Consumer Credit Protection Act, December 13, 1967. 


\section{Table 1}

\section{Key Disclosure Provisions of Regulation Z}

\begin{tabular}{|c|c|}
\hline Timing & Terms Disclosed \\
\hline Upon Application or Solicitation & $\begin{array}{l}\text { - } \text { Annual percentage rate (including penalty rates) for } \\
\text { - } \quad \text { Fees for issuance or availability (e.g., annual fees) } \\
\text { - } \quad \text { Minimum finance charge } \\
\text { - } \quad \text { Grace period } \\
\text { - } \quad \text { Statement on charge card payments } \\
\text { - } \quad \text { Cash advance fee } \\
\text { - } \quad \text { Late payment fee } \\
\text { - } \quad \text { Balance transfer fee }\end{array}$ \\
\hline Before First Use & $\begin{array}{l}\text { - } \text { Grace period } \\
\text { - Periodic rates used to calculate finance charges and } \\
\text { corresponding annual percentage rates } \\
\text { - } \text { Balance computation method } \\
\text { The amount of any significant charge, other than a finance } \\
\text { charge, that may be imposed as part of the plan, or an } \\
\text { explanation of how the charge will be determined (e.g., late } \\
\text { fees, over limit fees, statement copy fees, annual fees, } \\
\text { account closure fees) } \\
\text { - Any applicable security interest } \\
\text { - Consumers' billing rights }\end{array}$ \\
\hline On Periodic Statements & $\begin{array}{ll} & \text { Previous balance } \\
\text { - } & \text { Identification of transactions } \\
\text { - } & \text { Credits } \\
\text { - } & \text { Periodic rate and corresponding annual percentage rate } \\
\text { - } & \text { Amount of financh finance charge } \\
\text { - } & \text { Other charges } \\
\text { - } & \text { Closing date of billing cycle } \\
\text { - } & \text { Free-ride period } \\
\end{array}$ \\
\hline
\end{tabular}

Source: Regulation Z 


\section{Table 2}

\section{An Example of a Typical "Schumer box" Disclosure}

\begin{tabular}{|l|l|}
\hline $\begin{array}{l}\text { Annual percentage rate } \\
\text { (APR) for purchases }\end{array}$ & $\begin{array}{l}2.9 \% \text { until } 11 / 1 / 00, \\
\text { after that, 14.9\% }\end{array}$ \\
\hline Other APRs & $\begin{array}{l}\text { Cash-advance APR: } 15.9 \% \\
\text { Balance-transfer APR: } 15.9 \% \\
\text { Penalty rate: } 23.9 \% \text {. See explanation below. }\end{array}$ \\
\hline Variable-rate information & $\begin{array}{l}\text { Your APR for purchase transactions may vary. The rate is determined } \\
\text { monthly by adding } 5.9 \% \text { to the Prime Rate }\end{array}$ \\
\hline $\begin{array}{l}\text { Grace period for repayment of } \\
\text { balances for purchases }\end{array}$ & 25 days on average \\
\hline $\begin{array}{l}\text { Method of computing the } \\
\text { balance for purchases }\end{array}$ & Average daily balance (excluding new purchases) \\
\hline Annual fees & None \\
\hline Minimum finance charge & $\$ .50$ \\
\hline $\begin{array}{l}\text { Transaction fee for cash advances: } 3 \% \text { of the amount advanced } \\
\text { Balance-transfer fee: } 3 \% \text { of the amount transferred } \\
\text { Late-payment fee: } \$ 25 \\
\text { Over-the-credit-limit fee: } \$ 25\end{array}$ \\
\hline
\end{tabular}

* Explanation of penalty.

**The Prime Rate used to determine your APR is the rate published in on the day of the prior month.

Source: Regulation Z, Appendix G 
Table 3

\begin{tabular}{|c|c|}
\hline \multicolumn{2}{|r|}{ Convenience and Service Fee Changes Observed Among Top Issuers 1997-2002 } \\
\hline $\begin{array}{l}\text { Fees } \\
\text { Revised }\end{array}$ & $\begin{array}{l}\text { - The cash advance fee, both as a rate and minimum dollar amount, generally } \\
\text { increased from } 2 \% \text { with a } \$ 2 \text { minimum to } 3 \% \text { with a } \$ 15 \text { minimum; } \\
\text { The definition of a transaction eligible for a cash advance fee was } \\
\text { broadened in some cases to include wire transfers, money orders, traveler's } \\
\text { checks, lottery tickets, bets, and casino chips; and } \\
\text { - The minimum finance charge was increased by one large issuer from } \$ 0.50 \\
\text { to } \$ 1.00 \text {. }\end{array}$ \\
\hline $\begin{array}{l}\text { Fees } \\
\text { Added }\end{array}$ & $\begin{array}{l}\text { - A stop payment fee on credit card convenience checks ranging from } \$ 29 \text { to } \\
\$ 35 \text { was introduced; } \\
\text { - An additional credit card fee for extra cards of } \$ 5 \text { was introduced; } \\
\text { - A phone/Internet payment or convenience fee of } \$ 10 \text { to } \$ 25 \text { was introduced; } \\
\text { - A credit card convenience-check fee of } 3 \% \text { with varying minimums and } \\
\text { maximums was introduced; } \\
\text { - A person-to-person money transfer fee of } 3 \% \text { with varying minimums and } \\
\text { maximums was adopted; } \\
\text { - A statement or sales slip photocopy fee of } \$ 5 \text { to } \$ 10 \text { was introduced; } \\
\text { - A balance transfer fee of } 3 \% \text { with various fee minimums and maximums } \\
\text { was introduced; and }\end{array}$ \\
\hline
\end{tabular}

Source: Author's lender-borrower contract research 


\section{Table 4}

\section{Computation Technique Changes Observed Among Top Issuers 1997-2002}

- Payment Allocation

See text.

- Compounded Interest

See text.

- Double-Cycle Interest

See text.

- Transaction Date Interest

Some issuers changed their agreements to point out that "finance charges will begin to accrue from the date of the transaction for purchases" instead of from the posting date of the purchase. Similar changes were observed for the balance calculations of cash advances, credit card convenience checks, and balance transfer checks. This modification effectively increases yield by allowing issuers to accrue interest on a transaction amount before having to pay for it.

- Fee Interest

Modifications to the processing of payments and transactions have enabled issuers to earn interest on fees. For example, issuers changed the terms under which an over-limit fee could be assessed. In an agreement from 1997, one issuer explained that a fee would be imposed when "your account exceeds your credit limit unless your account is not over limit by the end of the billing cycle." In 2002, the same issuer explained, "An overlimit fee is assessed to your account as of the day in the billing cycle that your total outstanding balance exceeds your credit limit." Similar language changes pertaining to late fees were observed in many lender-borrower contracts. By assessing over-limit and late fees at the point of the infraction (which could be at the beginning or middle of the cycle), instead of at the end of the cycle, issuers can earn finance charges on fees.

\section{- Residual Interest}

Revolving customers who send in a payment to completely pay off their debt may have to make another payment to eliminate their balance because of residual interest charges. To achieve this, one issuer amended its agreements in the late 1990s as follows: "Finance charges will be assessed on previous purchase balances if your account was not paid in full in the previous billing cycle, even if we receive a payment in full in the current billing cycle." This means that a revolving customer who sends in the amount indicated on his or her statement as "Now Due" would be assessed finance charges the next month for the period between when the statement was generated and when the payment was received. Consider a customer who had an interest rate of 10 percent and a revolving balance of $\$ 1000$. If this customer mailed in a payment for $\$ 1000$ that was received by the issuer 25 days after the statement was generated, he or she would get a bill the next month for 25 days' worth of interest, or approximately $\$ 6.85$.

Source: Author's lender-borrower contract research 
Figure 1

\section{Billions of US Credit Card Acquisition Mailings 1991-2001}

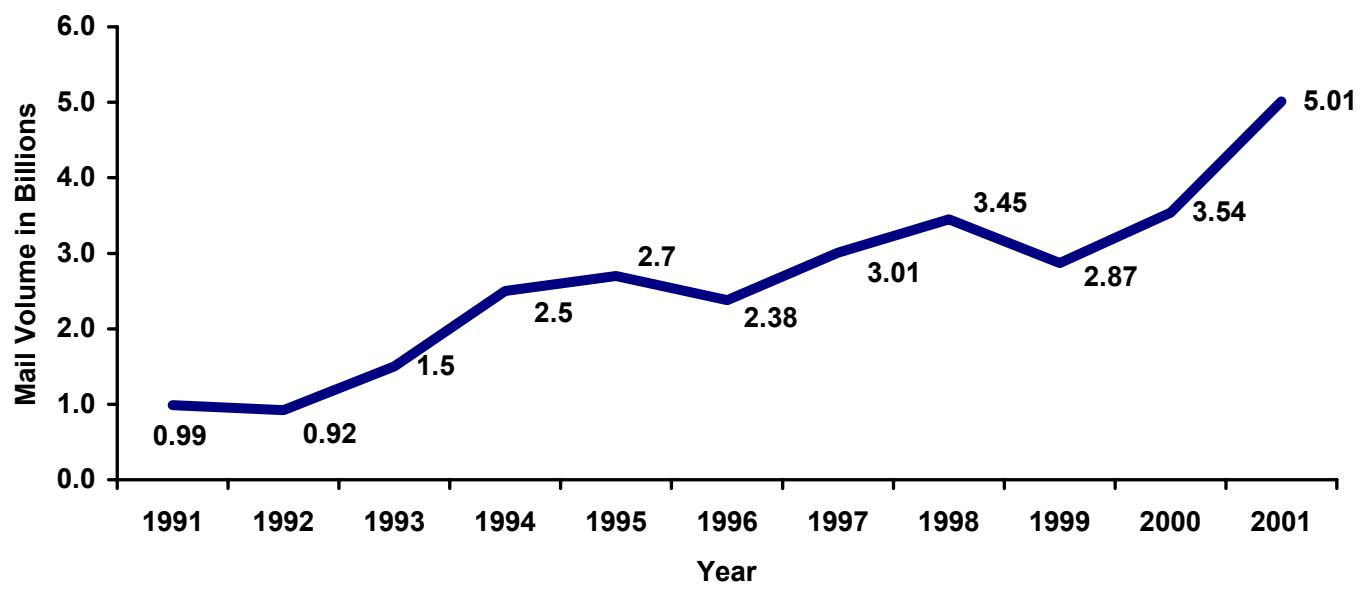

Source: BAI Global Mail Monitor 
Figure 2

\section{Avg. Credit Card Rate* vs. 6 Mo. T-Bill \\ 1972-2002}

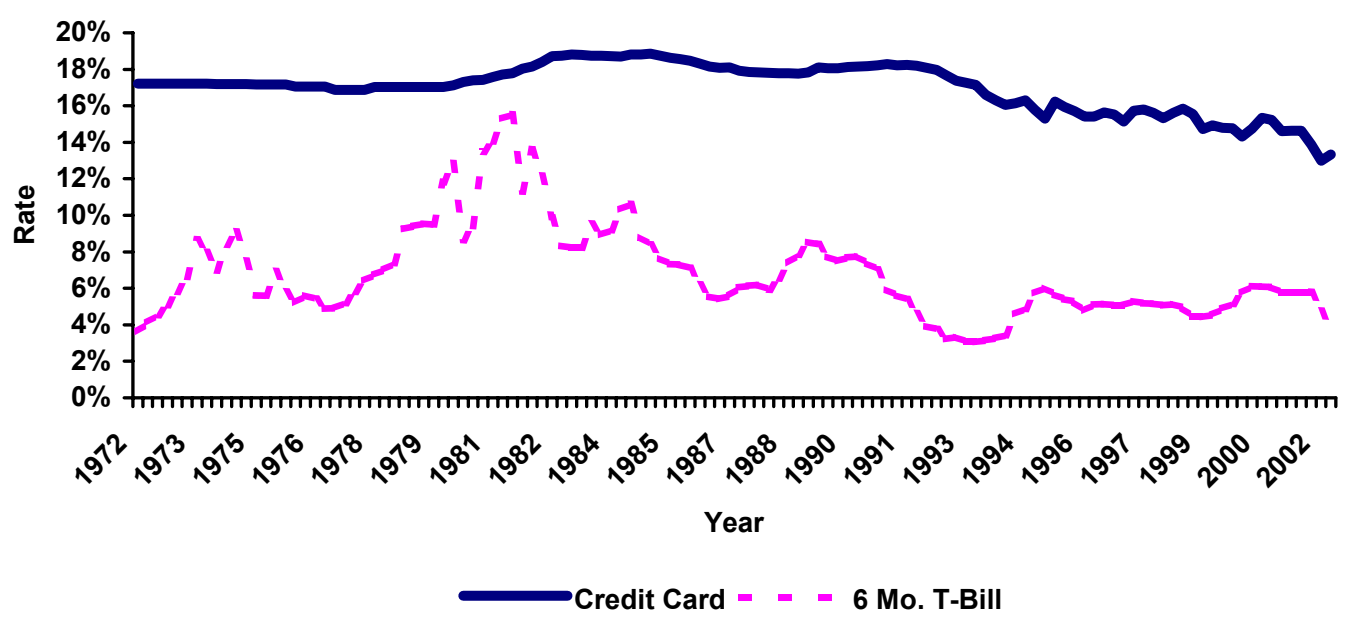

*This is the average rate charged by commercial banks as reported in the Federal Reserve's G.19 statistical release. For 1994 to present, the average is among consumers with a credit card who were assessed interest.

Source: Federal Reserve Statistical Release G.19- Consumer Credit 
Figure 3

\section{Average Credit Card Markup*}

1992-2001

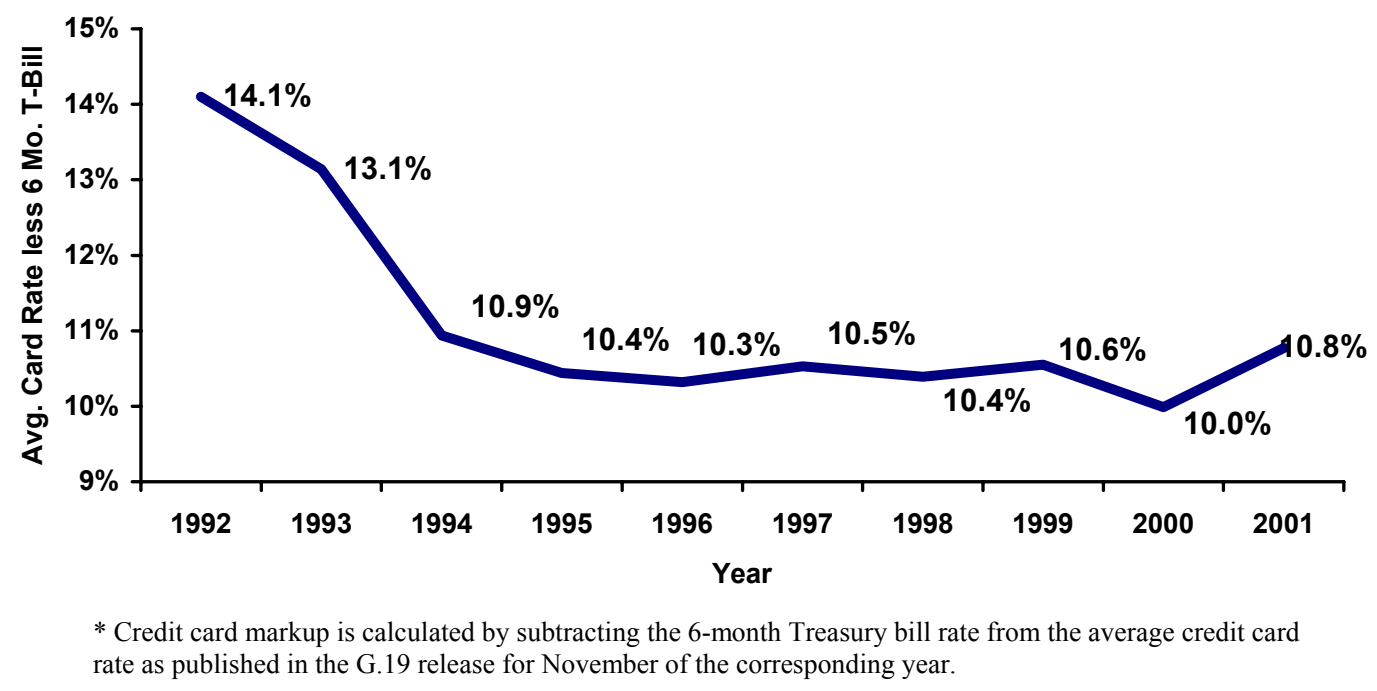

Source: Federal Reserve Statistical Release G.19- Consumer Credit 
Figure 4

Diff. Between Personal Loan \& Card Loan*

1986-2001

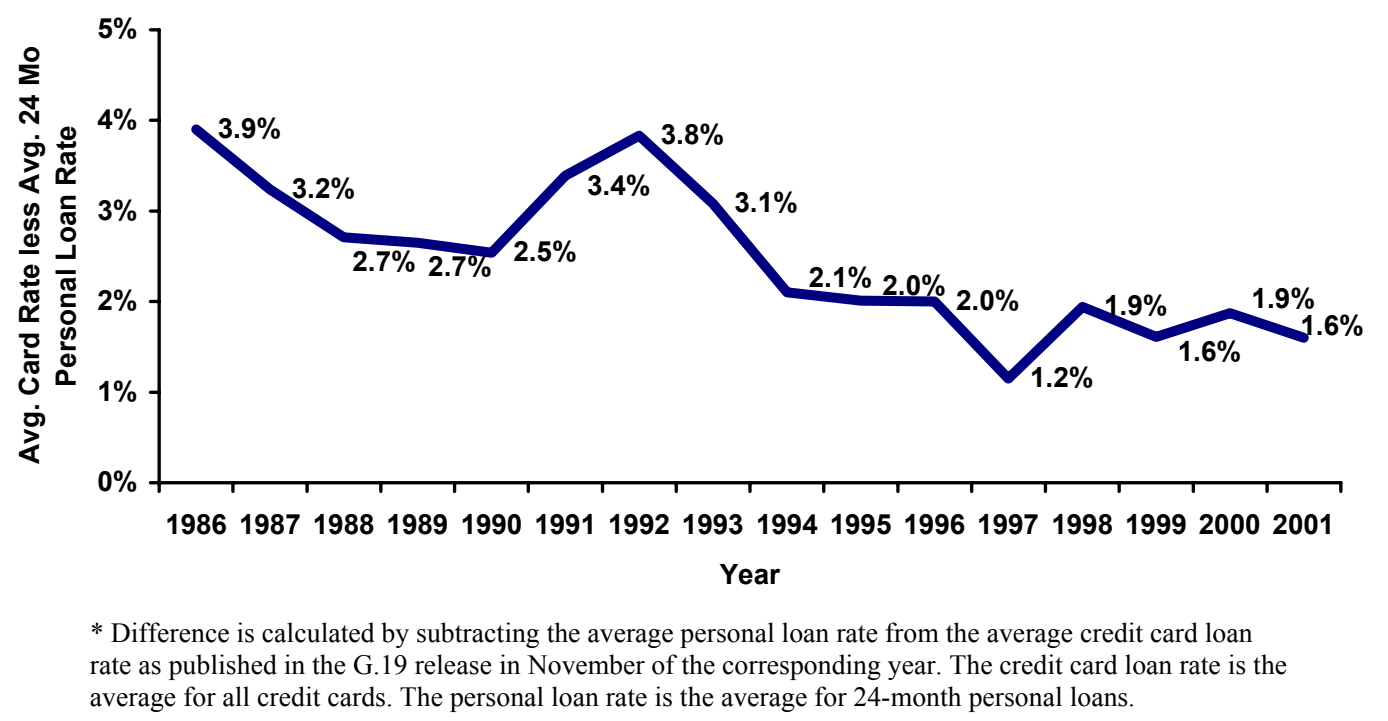

Source: Federal Reserve Statistical Release G.19- Consumer Credit 
Figure 5

\section{Diff. From Highest Risk Cohort's Finance Charge Yield "Borrower Quality" Discount}

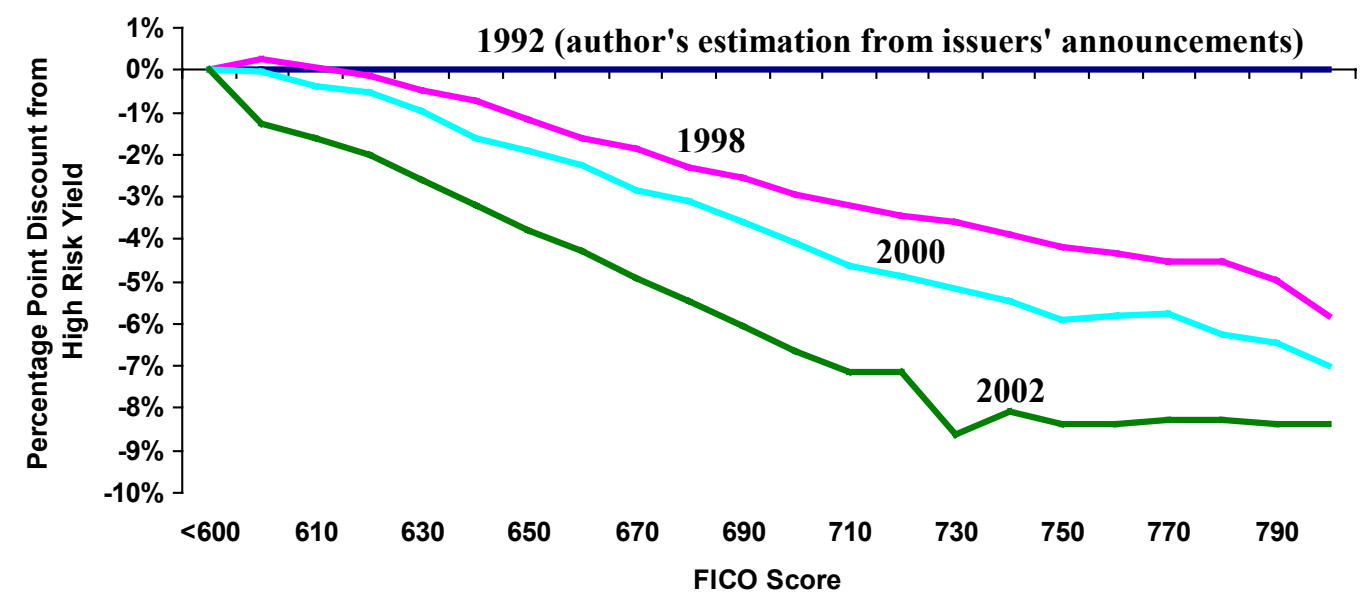

Source: Argus Information \& Advisory Services 
Figure 6

\section{Fee Income as a Percentage of Total Revenue* 1990-1999}

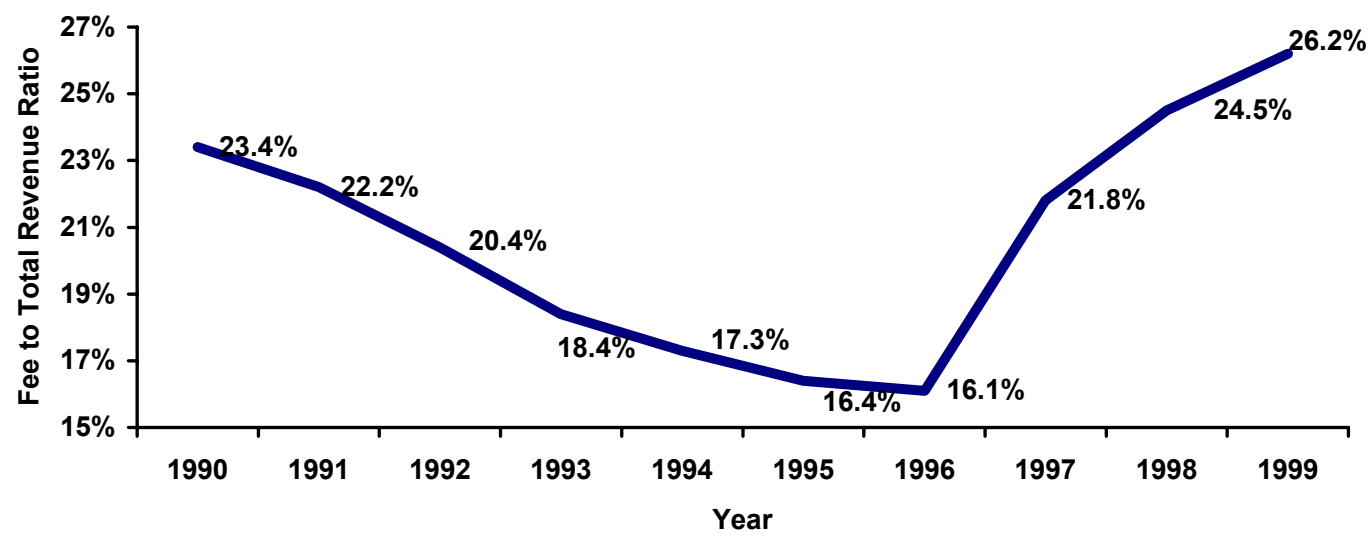

* Fee income does not include fees from securitization. Ratio is calculated by dividing credit card fee income for industry by the sum of the credit card interest income for the industry and the total credit card fee income for industry as reported by CardWeb.

Source: October 1999 and July 2000 issues of CardTrack, CardWeb.com 
Figure 7

\section{Average Late Fee Being Assessed* 1994-2002}

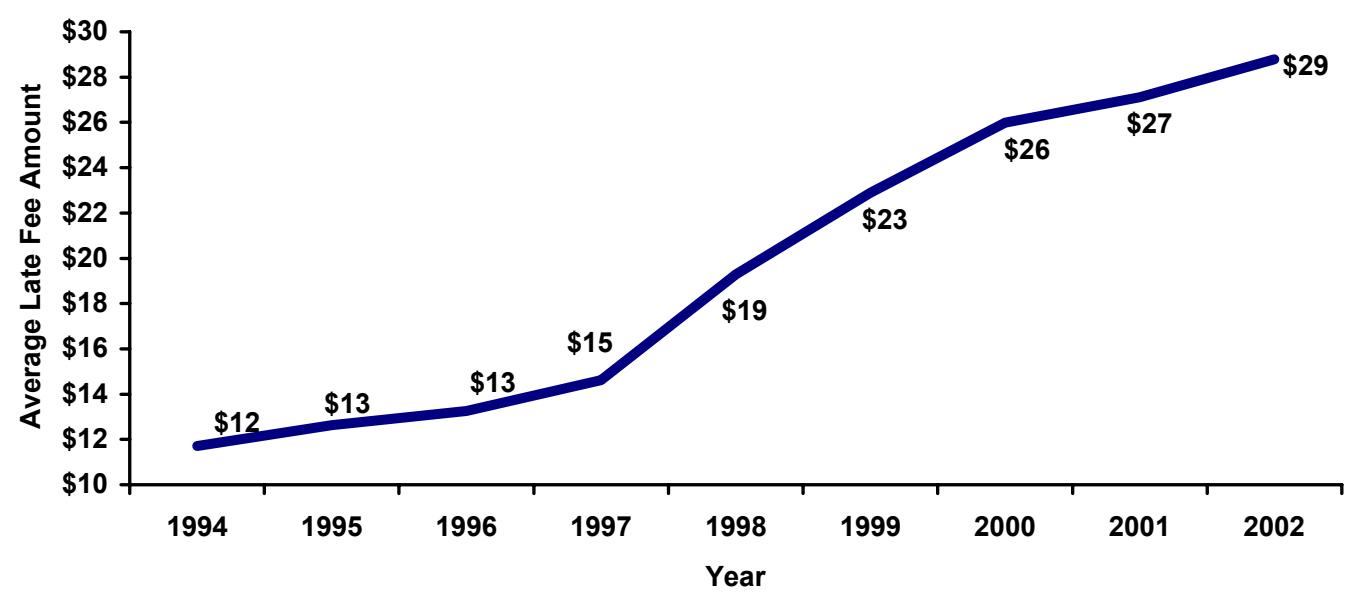

*Average late fee being assessed by "large issuers" as defined by CardWeb.com. Note that the average late fee increased $145.8 \%$ from 1994 to 2002 while the Consumer Price Index increased $21.4 \%$ for the period.

Source: March 21, 2002 issue of CardTrack, CardWeb.com 